\title{
The Exploration of the Influence of Open University Students' Learning Motivation on Vocabulary Attrition
}

\author{
Huang Yu, Tang Qi \\ Female Lecturer Master's Degree Nanchong City Sichuan Province, Sichuan Open University
}

\begin{abstract}
In the field of language study, vocabulary attrition is a hot topic which attracts many language researchers' attention and has made a lot of achievements at home and abroad. Different researchers study the vocabulary attrition based on various aspects. Based on the previous studies, this study mainly explores the influence of students' motivation on vocabulary attrition. The subjects of this research are the Open University students who have the typicallearning motivation. Through questionnaire and analysis, this study aims to find out what kind of learning motivation and how's the motivation affect the vocabulary attrition. Finally, the author offers some suggestions for vocabulary teaching and learning in Open University with the purpose of minimizing English vocabulary attrition.
\end{abstract}

Keywords: vocabulary attrition; motivation; influence; Open University students

\section{INTRODUCTION}

In the process of language learning, vocabulary attrition is a common phenomenon among different group of language learners. For the study of factors affecting the vocabulary attrition is of great significance. However, after reading relative studies, the author found that many previous researchers have done this topic based on college students and middle school students. There are few researches basing on Open University students. So, there exists research blank which gives the author space to do this study.

In modern English, the word attrition refers to: (1) the act of weakening or exhausting by constant harassment, abuse, or attack (a war of attrition). (2) A reduction in numbers usually as a result of resignation, retirement, or death (a company with a high rate of attrition). (Merriam-Webster's Online Dictionary)Language attrition, as a branch in linguistics, has gained importance in research and caught many researchers' attention since a conference held at the University of Pennsylvania on the attrition of language skills. In that conference, language attrition was broadly defined as the loss of any language or any portion of a language by an individual or a speech community. (Freed, 1982) The detailed definition is as follows:

Broadly defined, language attrition may refer to the loss of any language or any portion of a language by an individual or a speech community. It may refer to the declining use of mother tongue skills by those in bilingual situations or among ethnic minorities. In some Language contact situations where one language, for political or social reasons, comes to replace another. Language attrition also refers to the deterioration of language skills in neurologically impaired patients and to the decline of certain types of language usage by the elderly. Likewise, language attrition may be used to describe the death of an entire language. There is yet another sense in which the term language skill attrition is used which has received considerably less attrition. That is the loss of language skills by those who have studied and then discontinued the use of a second language.

In this study, the definition of language attrition may refer to the loss of any language or any portion of a language by an individual or a speech community.

As for the learning motivation, motivation is one of the key decisions of non-intellectual factors to foreign language learning success, and its role is to stimulate foreign language learning and the raw power of the subsequent learning process providing sustainable dynamic force. While, there are different types of learning motivation which may have different degree of influence on vocabulary attrition. 


\section{THE RESEARCH MethOdOLOGY}

\subsection{Research Questions}

1) For Open University students, what's their motivation types can be classified into? Which kind of motivation is more obvious?

2) For Open University students, what is the influence of motivation on vocabulary attrition? Whether there are significant differences among the different motivation types?

\subsection{Research Instrument}

In this study, based on the research question and purpose, and in order to ensure the validity andreliability, the author mainly uses questionnaire to carry out the whole study. Questionnaire is good for its two advantages. First, it is easy to carry out with a large number of students at the same time. Second, the data collected is easy to deal with for its unified form. The questionnaire in the study is used in Chinese for the purpose of avoiding misunderstanding by the low proficiency students. The questionnaire is designed based on GaoYihong's (2003) English Learning Motivation Investigation for her questionnaire is more accorded with Chinese English language learners' the real situation. Three types of motivation are included in the questionnaire; they are respectively Situational Motivation, Instrumental Motivation, and Cultural Motivation.

\subsection{Research Subjects}

In terms of research subjects, this research mainly explores the Open University students, so the subjects selected are the 148 students in Nanchong Open University. They are non- Englishmajors and they major in education management and administrative management. So, most of them are relatively poor in English.

Table1. Distribution of the Samples

\begin{tabular}{|l|l|l|l|l|}
\hline \multirow{2}{*}{} & \multicolumn{2}{|l|}{ Gender } & Major \\
\cline { 2 - 5 } & Male & Female & education management & administrative management \\
\hline $\mathrm{N}$ & 87 & 61 & 52 & 96 \\
\hline Sum & 100 & 100 & \\
\hline
\end{tabular}

\subsection{Data Collections}

As for the data collection, it lasts 2 months during which all the participants answered questionnaire. The questionnaire was asked to finish in their regular lesson of English course within thirty minutes, and students were encouraged to do the questionnaire honestly and independently.Meanwhile, the subjects were told again in Chinese that the answers they provided had nothing to do with their credits during their four years' study. All the questionnaires were collected by the researcher. After a period of time, questionnaire was finished again by students at the early new term. The students were told that the question was so important that they should take it seriously. After the data were collected, the author picked out those data with little help to this study. Then identified the right answers done by the participants, each multiple choice with correct answers done by the subjects will be given one score.

\section{RESULTS AND DISCUSSION}

This part consists of the results and discussion of the data collected during two months, and the data are processed according to the twoquestions.Firstly, different types of motivations are identified according to the questionnaires collected in the study. Then, the influences of different motivation types on vocabulary attrition are investigated.

\subsection{Results}

\subsubsection{The Motivation Type and the Degree of Motivation}

According to the data collected, students have different motivations. Among the three different types, instrumental motivation is the highest motivation owned by one hundred and two participates, which covers 68.92 percentage in the total people. Ten students belong to the cultural motivation type, which covers 6.76 percentages in the total people. Thirty six students belong to the situational motivation types which covers 24.32 percentages in the total people. From the table, it is obvious that instrumental motivation is the most frequent among the Open University students. 
The Exploration of the Influence of Open University Students' Learning Motivation on Vocabulary Attrition

Table2. Distribution of Motivation Types

\begin{tabular}{|c|c|c|}
\hline motivation types & $\mathrm{N}$ & Percentage \\
\hline Instrumental Motivation & 102 & $68.92 \%$ \\
\hline Cultural Motivation & 10 & $6.76 \%$ \\
\hline Situational Motivation & 36 & $24.32 \%$ \\
\hline Sum & 148 & $100 \%$ \\
\hline
\end{tabular}

Table 3 shows the descriptive statistics of different motivation types. In table 3 , it shows that the mean score, std. deviation and std. error mean of instrumental motivation are respectively 3.9, 1.76, and 0.18. The mean score, std. deviation and std. error mean of cultural motivation are respectively 3.2, 1.45, and 0.48 . The mean score, std. deviation and std. error mean of cultural motivation are respectively $2.4,1.12$, and 0.19 . The mean score, std. deviation and std. error mean of whole motivation are respectively 3.5 , 1.62 and 0.14 . The mean of cultural motivation and instrumental motivation are placed the highest among the three while the lowest motivation is cultural motivation. It is further verified that instrumental motivation manifest the strongest of the whole participates while the cultural motivation manifest the weakest.

Table3. Descriptive Analysis for Motivation Types

\begin{tabular}{|c|c|c|c|c|c|}
\hline Types & $\mathrm{N}$ & Mean & Std. D & Std.E Mean & df \\
\hline Instrumental Motivation & 102 & 3.9 & 1.76 & 0.18 & 101 \\
\hline Cultural Motivation & 10 & 3.2 & 1.45 & 0.48 & 9 \\
\hline Situational Motivation & 36 & 2.4 & 1.12 & 0.19 & 35 \\
\hline Motivation & 148 & 3.5 & 1.62 & 0.14 & 147 \\
\hline
\end{tabular}

\subsubsection{The Influence of Motivation on Vocabulary Attrition}

The final purpose of the study is to explore the influences of different types of motivations on vocabulary attrition of Chinese Open University Students. One way ANOVA analysis in SPSS is used to find out the influences of different motivation on vocabulary attrition.

Table 4 shows that the mean score, std. deviation and std. error mean of the group of instrumental motivation are respectively $80,37.22$, and 3.72 while after a period of is $68,31.54$, and 3.15.

The mean score, std. deviation and std. error mean of the Group of cultural motivation are respectively 69, 32.08 and 10.14 .The mean score, std. deviation and std. error mean of the Group of situational motivation are respectively 50, 23.74 and 3.96. Based on those data, the scores of the words in earlier time are all higher than after a period time, and the sig value of the groups instrumental motivation and situational motivation areall lower than the sig value of 0.05 , which shows there is a words decline between the two period of time in related to those groups. However, participates with strong cultural motivation experienced less vocabulary attrition.

Table4. Descriptive Statistics of the Words with Different Motivation Types

\begin{tabular}{|c|c|c|c|c|c|}
\hline Motivation Types & & ean & Std. D & Std.EMean & df sig.(2-tailed) \\
\hline \multirow{3}{*}{ Instrumental Motivation } & 102 & 80 & 37.22 & 3.72 & 101 \\
\hline & 102 & 68 & 31.54 & 3.15 & 101 \\
\hline & 102 & 12 & 48.79 & 4.88 & 101.012 \\
\hline \multirow{3}{*}{ Cultural Motivation } & 10 & 69 & 32.08 & 10.14 & 9 \\
\hline & 10 & 48 & 21.39 & 6.77 & 9 \\
\hline & 10 & 37 & 38.56 & 12.20 & 9.06 \\
\hline \multirow{3}{*}{ Situational Motivation } & 36 & 50 & 23.74 & 3.96 & 35 \\
\hline & 36 & 21 & 9.86 & 1.99 & 35 \\
\hline & 36 & 29 & 25.71 & 4.29 & 35.00 \\
\hline
\end{tabular}

To investigate whether certain type of motivation influence more on vocabulary attrition, one way ANOVA is performed in the continued study. Table 5is the output of one way ANOVA 
In Table 5, between the three groups of motivation, the sum of squares is 6156.75 and Mean square is 2052.25. At the significant level of 0.05 , the sig. value between the group is $0.00(p=.000<0.05)$, which shows that significant attrition differences exist among the three groups of words with different motivation type.

To make the results more clearly, a further multiple comparison of each two groups is run. And Table 5 shows a multiple comparison between the group of instrumental motivation and the group of cultural motivation, the group of situational motivation and the group of cultural motivation, and between the group of instrumental motivation and situational motivation respectively. The mean differences and std, error of each two groups are respectively 11 and 4.98, 30 and 13.27, 19 and 7.84.

At the significant level of 0.05 , there are significant differences between the group of instrumental motivation and the group of cultural motivation, and between the group of instrumental motivation and situational motivation, because the sig value of those groups are all lower than 0.05 . However, there is significant difference is found between the group of situational motivation and the group of cultural motivation $(\mathrm{p}=0.16>0.05)$, which indicates subjects with strong instrumental motivation experienced vocabulary attrition soeasily. And subjects with strong situation motivation experienced word attrition moderately. Lastly, participates with strong cultural motivation experienced vocabulary attrition not easily.

Table5. One Way ANOVA of the Words with Different Motivation Types

\begin{tabular}{|c|c|c|c|c|c|}
\hline & Sum of Squares & df & MeanSquare & F & Sig. \\
\hline Between Groups & 6156.75 & 3 & 2052.25 & 3.01 & .00 \\
\hline Within Group & 98180.73 & 144 & 681.81 & & \\
\hline Total & 104337.48 & 147 & & & \\
\hline
\end{tabular}

\subsection{Discussion}

In this study, the main difference is the research subjects who are the Open University students and recognized a special group of people. As is shown in above results, they have typical features in learning motivation, and there is significant influence on the vocabulary attrition for them. Therefore, this result gives some implications to Open University students and teachers.In Open University, teacher are supposed to pay more attention on long term retaining of English words, but not the immediate English words learning achievements in the learning process of English words.Affective factors, especially motivation play important role in maintaining vocabulary. Students with strong and positive motivation can effectively resist language attrition (Gardner, 1987; Vivian Cook, 2000; Weltens, 1993). Therefore, for Open University students, attention should be paid on the learners' motivation by English teachers. A harmonious relationship with students is the essential requirement. The most important thing is to promote Open University students' cultural motivation for the cultural motivation can help resist vocabulary attrition.

\section{Conclusions}

Based on the data, the research questions can be answered. Firstly, for Open University students, there are mainly three types of motivation can be classified. They are instrumental motivation cultural motivation, and situational motivation. And instrumental motivation is the most frequent among the Open University students and the cultural motivation manifest the weakest. Secondly,for Open University students,cultural motivation is proved to retain English words better than the other types of motivation.

\section{REFERENCES}

Brown, H. D. (1990). M\&Ms for language classrooms?Another look at motivation.In J. Alatis (Ed.), Georgetown University round table on language and linguistics, (pp. 383-393). Washington, DC: Georgetown University Press.

Cohen, Andrew D. 1986. Forgetting foreign language vocabulary.In Weltens, Bert, Kees DeBot \& Theo Van Els (eds.) Language attrition in progress[C].Dordrecht, Holland: Foris, 143-158.

Freed B F. Language loss: current thought and future directions [A].// Lambent R D, Freed, B F, The lass of language skills. Rowley, MA: Newbury House, 1982: 207-223. http://www.merriam -webster.com/dictionary/attrition

Gardner, R. C. (1985). Social psychology and second language learning: The role of attitudes and motivation. London: Edward Arnold 
Gardner. R.C..\&W. E. Lambent. 1972. Attitudes and Motivation in Second Language Learning. [M].Rowley, Mass.: Newbury House

Gardner, R. C., Lalonde, R. N, \& Moorcroft, R. (1987). "Second Language Attrition: the role of motivation and use". Journal of Language and Social Psychology; Vol. 6, No. 1: 29-47.

Muijs,D. (2004) Doing Quantitative Research in Education with SPSS, Sage Publication.

Schmidt, R., Boraie, D., \&Kassabgy, O. (1996). Foreign language motivation: Internal structure and external connections. In R. Oxford (Ed.), Language learning motivation: Pathways to the new century (Technical Report \#11) (pp. 9-70). Honolulu: University of Hawaii, Second Language Teaching and Curriculum Center.

Weltens, Bert \&Marjon Grendel. 1993. Attrition of vocabulary knowledge.Studies in Bilingualism 6 (KUN) [also in Robert Schreuder \& Bert Weltens (eds.). The Bilingual Lexicon[C]. Amsterdam: John Benjamin, 135-156.

Weltens, B. The Attrition of Foreign-language Skills: A Literature Review Applied Linguistics [J].1987(8): 22-37.

刘巍英语水平与学习动机对词汇磨蚀影响的实证研究天津外国语学院学报 2010 年 1 月第 17 卷 第 1 期

倪传斌情感因素对外语磨蚀群体目标语接触量的影响一基于数据挖掘的建模与分类外语教学理 论与实践 2010 年第 1 期

高一虹、赵媛、程英、周燕，中国大学本科生英语学习动机类型现代外语(季刊) 2003,第 26 卷 第 1 期 